\title{
ATF4 wt Allele
}

National Cancer Institute

\section{Source}

National Cancer Institute. ATF4 wt Allele. NCI Thesaurus. Code C107458.

Human ATF4 wild-type allele is located in the vicinity of 22q13.1 and is approximately $3 \mathrm{~kb}$ in length. This allele, which encodes cyclic AMP-dependent transcription factor AT F-4 protein, is involved in the regulation of gene transcription. 